\title{
TAFSIR AYAT RAHMATAN LIL 'ALAMIN MENURUT PENAFSIR AHLU SUNNAH, MUKTAZILAH, SYIAH, DAN WAHABI
}

\author{
Lukman \\ Dosen Program Studi Pendidikan Agama Islam FIAI UII Yogyakarta \\ Email: lukman.ahmadirfan@uii.ac.id
}

\section{Abstract}

This study aims to determine whether the source of conflict in the body of the Muslims also caused differences in the interpretation of paragraph rahmatan lil 'Alamin in Surat al-Anbiya' verse 107. This limits the research object of research only on four major currents of thought in Islam, namely Ahlu Sunnah, Mu'tazilite, Shia and Wahabi. According to the flow Ahlu Sunnah that are faithful to God, the grace bestowed in this world and hereafter. For those who do not believe in Allah SWT, then the form of grace is not disegerakannya catastrophe in the world as the peoples before Islam. Then interpretation Mu'tazilite flow, explicitly the existence of a disadvantage for non-believers. That the Prophet Muhammad brought happiness to those who followed him and who did not follow it, then it comes out of his lust which constrict parts of grace. Furthermore, the flow Shiite explicitly showing reluctance for people who do not believe in the grace. That Allah showed unbelievers to believe and give him the signs, but the unbelievers not find it. Lastly, the interpretation of Wahabism that explicitly rampart against the unbelievers. That mercy for the infidels against Islam is to be speeded up his death and it is better for them. Because with no faith and hostility they will just tuck torment in the hereafter

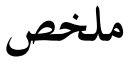

$$
\begin{aligned}
& \text { وتمدف هذه الدراسة إلى تحديد ما إذا كان مصدر الصراع في جسم المسلمين تسببه } \\
& \text { أيضا اختلافات في تفسير أية "رحمة للعالمين" في سورة الأنبياء الآية V • ا. ـ تحدد } \\
& \text { الدراسة للبحوث فقط على أربعة تيارات الفكرالرئيسيفي الإسلام، وهي جماعة أهل }
\end{aligned}
$$

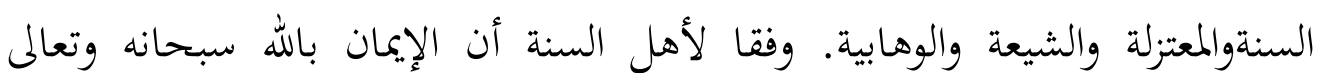




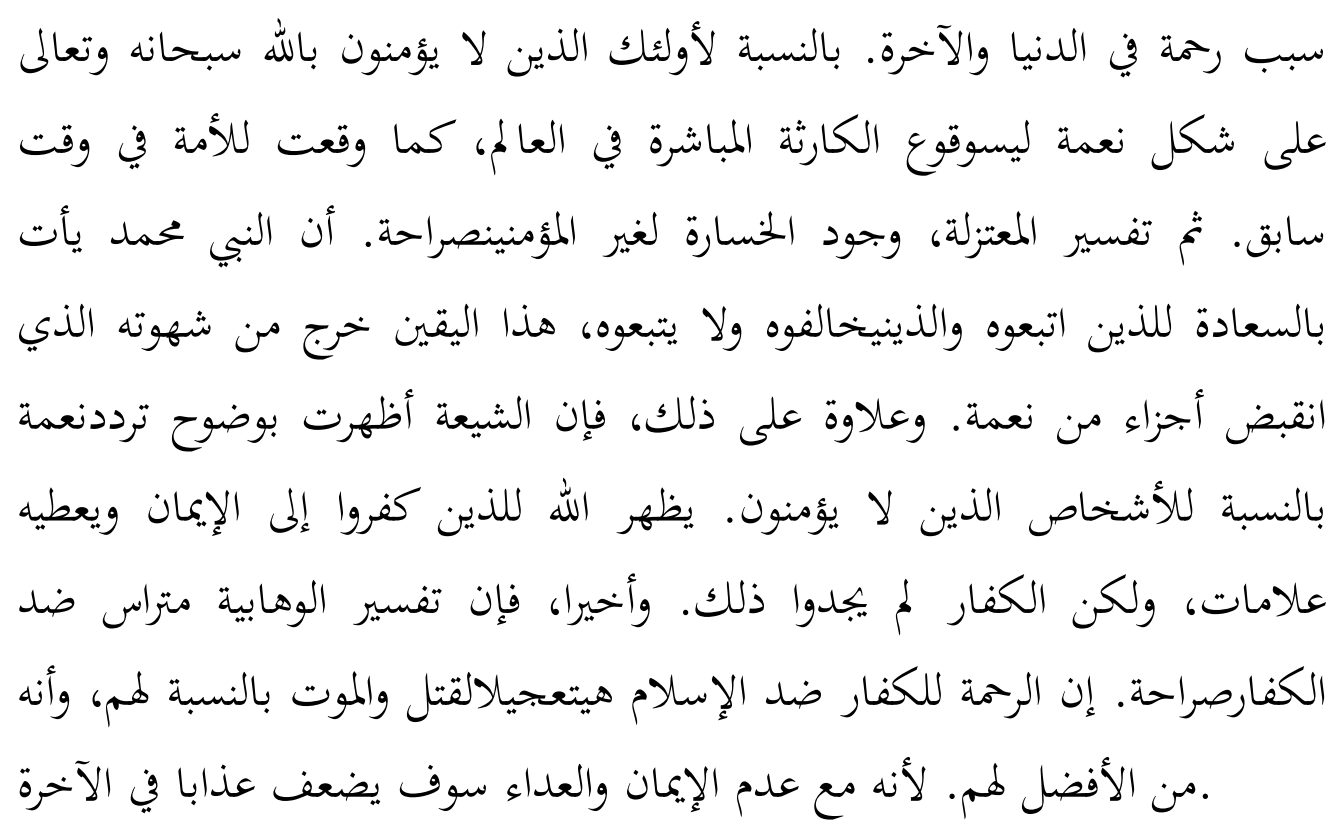

Keywords: Perbedaan, Penafsiran, Rahmatan lil 'alamin

\section{A. Pendahuluan}

Islam adalah agama yang Rahmatan lil 'Alamin. Pernyataan ini dewasa ini sangat sering dikemukakan sebagai pemahaman bahwa Islam adalah agama rahmah, kasih sayang terhadap sesama manusia dan alam semesta serta kontra terhadap kekerasan dan agresivitas terhadap sesama manusia dan alam semesta. Pemahaman ini diambil dari sumber utama ajaran Islam, yaitu Al-Qur'an, pada surat al-Anbiya' ayat 107: "dan kami tidak mengutus kamu (Muhammad) melainkan untuk (menjadi) rahmat bagi semesta alam". Hal ini menunjukkan bahwa agama Islam adalah agama untuk semua makhluk Allah SWT (universal), tidak terbatasi geografi, suku, bangsa, dan ras, bahkan agama ini juga diserukan untuk para jin.

Wujud dari pemahaman ini adalah pemeluk agama Islam yang saleh adalah pribadi yang Rahmatan lil 'Alamin, dengan teladan utama Nabi Muhammad SAW. Namun, sungguh mengherankan betapa ajaran yang indah ini tidak menemukan kenyataannya di banyak pribadi Muslim di Indonesia kalau dilihat dari perkembangan sosial masyarakat Indonesia, bahkan juga di daerah asalnya 
di Jazirah Arab. Di Indonesia, Selama satu dekade terakhir, kericuhan antar sesama Muslim semakin menjadi, bahkan bentrokan fisik yang menimbulkan korbanjuga terjadi: (1) Bentrok antara anggota Front Pembela Islam (FPI) dengan warga Sukorejo, Kabupaten Kendal pada 17 Juli 2013. Ketika itu terjadi, satu orang yang tewas (www.merdeka.com, Kamis, 31 Oktober 2013); (2) Konflik Syiah di Sampang pada bulan Agustus 2012 yang menyebabkan korban 1 orang tewas, 4 orang kritis, dan puluhan rumah terbakar (Koran Tempo, 27 Agustus 2012); (3) Bentrok Warga Kecamatan Blora dengan Anggota Majelis Tafsir AlQur'an (MTA) pada 13 Juli 2012 (www.merdeka.com tanggal 14 Juli 2012); (4) Kasus penyerangan Jemaat Ahmadiyah di Cikeusik, Banten pada 6 Februari 2011 yang menyebabkan terjadinya perusakan, penganiayaan, dan pembunuhan (www.suarapembaruan.com tanggal 9 Agustus 2011); (5) Kasus Tanjung Priok pada April 2010 terjadi antara massa berbendera agama dengan pemerintah, ada tiga satpol PP tewas, 69 luka dan 36 mobil rusak (news.viva.co.id tanggal 9 Februari 2011); (6) Kericuhan Warga Muhammadiyah dan Nahdlatul Ulama (NU) di Desa Kaligung Rogojampi, Banyuwangi pada Oktober 2007 (news. liputan6.com tanggal 26 Oktober 2007). Sementara di Arab juga tidak berbeda, sesama Muslim saling berperang. Dan kesemuanya mengklaim pihaknyalah yang benar dengan mengemukakan tafsir mereka terhadap Al-Qur'an.

Begitu juga dengan tafsir terhadap ayat Rahmatan lil 'Alamin. Setiap pihak yang bertikai memposisikan pihak mereka sebagai pihak yang Rahmatan lil 'Alamin. Mereka berkata bahwa pihak mereka yang berpedomankan Al-Qur'an dan Hadis, pihak mereka memperjuangkan keadilan, menghapus kedzaliman dan kebodohan, dan banyak lagi argumentasi mereka untuk membenarkan pihak mereka. Saat mereka diingatkan sebuah hadis yang terkenal, Nabi Muhammad SAW bersabda: "tidak beriman seorang kamu sehingga sehingga kamu mencintai saudaramu sebagaimana mencintai dirimu sendiri". Mereka menjawab bahwa mereka bertikai adalah untuk mencintai mereka agar tidak sesat dan tidak musyrik. Amboi, sungguh sangat sulit berdiri tegak menjadi juri di antara mereka yang bertikai.

Oleh karenanya sungguh benar para pendiri negara Indonesia menjadikan "Bhinneka Tunggal Ika" sebagai semboyan kehidupan berbangsa dan bernegara. Semboyan ini adalah sebuah wujud untuk menghargai keanekaragaman. Menghargai orang lain karena sesungguhnya kebenaran mutlak adalah 
Allah SWT, sementara manusia hanya mempunyai tafsir kebenaran, bukan kebenaran itu sendiri. Walaupun untuk menjadi bijak menyikapi perbedaan tentu membutuhkan bekal pemahaman terhadap obyek itu sendiri secara menyeluruh.Terkait dengan bekal menyeluruh inilah, penelitian ini amatlah penting untuk dilakukan sebagai bekal pemahaman terhadap beragam pendapat mengenai Rahmatan lil 'Alamin.

Penelitian ini membatasi objek penelitian hanya pada 4 (empat) arus besar pemikiran dalam Islam, yaitu Ahlu Sunnah, Muktazilah, Syiah, dan Wahabi. Pembatasan pada 4 (empat) arus besar pemikiran dalam Islam ini mengingat sejarah peradaban Islam masa lalu yang dipandang mempunyai pengaruh besar dan ideologi dalam landasan berpikir dan menafsirkan. Selain itu, 4 (empat) aliran besar inilah yang tampak mewarnai dalam pemikiran dan praktik kegamaan Islam di dunia saat ini.

\section{B. Metode Penelitian}

Jenis penelitian ini adalah penelitian kepustakaan (library research). Menurut Noeng Muhadjir ${ }^{1}$ (1996) penelitian kepustakaan itu lebih memerlukan olahan filosofis dan teoritis daripada uji empiris di lapangan. Pustaka yang diteliti adalah dokumen kitab-kitab tafsir yang ditulis oleh para ulama penafsir dari aliran Ahlu Sunnah, Muktazilah, Syiah dan Wahabi. Fokus kajian penelitian ini adalah ayat Rahmatan lil 'Alamin Al-Qur'an Surat al-Anbiya' ayat 107. Penelitian ini bersifat deskriptif eksploratif yaitu mendeskripsikan hasil eksplorasi data tentang ayat Rahmatan lil 'Alamin.

Data primer penelitian ini adalah pendapat ulama ahli tafsir beraliran Ahlu Sunnah, Muktazilah, Syiah, dan Wahabi yang terdokumen dalam kitab tafsir mereka, yaitu: (1) Kitab Mafatih al-Ghoib karya Fakhruddin ar-Razi (544-606 H). Kitab ini dinilai oleh para ulama sebagai tafsir beraliran Ahlu Sunnah. Sumber kitab yang digunakan adalah "Ar-Razi, Fakhruddin. 1981. Mafatih al-Ghaib juz 13. Beirut: Dar al-Fikr.” (2) Kitab Fathu al-Qodir karya Imam As Syaukani (1173-1250 H). Kitab ini dinilai oleh para ulama sebagai tafsir beraliran Ahlu Sunnah. Sumber utama dalam memahami kita ini diambil dari “Syaukany,

1 Noeng Muhadjir. Metodologi Penelitian Kualitatif. Edisi Ke-3. (Yogyakarta: Rake Sarasin, 1996), hal. 169. 
Al-Imam Muhammad bin Aly bin Muhammad Asy. 2003. Fathul Qodir. Bairut Libanon: Darul Kutub Al-Ilmiyyah. (3) Kitab Al-Kasysyaaf'An Haqaa'iq at-Tanziil Wa 'Uyuun al-Aqaawiil Fii Wujuuh at-Ta'wiil karya Abu al-Qasim, Mahmud bin 'Umar bin Muhammad al-Khawarizmi, al-Hanafi, penganut aliran Muktazilah, yang dijuluki Jaarullah. Sumber utama yang digunakan dalam mengeksplorasi kitab ini adalah "Zamakhsari, Al-Imam Abi Qosim Jarulloh Mahmud bin Umar bin Muhammad Az-.2003. Al-Kasysyaaf 'An Haqaa'iq at-Tanziil Wa 'Uyuun alAqaawiil Fii Wujuuh at-Ta'wiil. Bairut Libanon: Darul Kutub Al-Ilmiyyah. (4) Kitab Majma' al-Bayan fi Tafsir al-Qur'an disusun oleh Abu Ali al-Fadll bin alHasan ai-Thabarsi (wafat 548 H). Al-Dzahabi (1986) menjelaskan bahwa kitab Tafsir Majma' al-Bayan ini adalah perpaduan Madzhab Syi' ah dan Mu'tazilah. Kecenderungan at Thobarsi sebagai mufassir yang mengikuti madzhab Syi'ah. Kitab yang digunakan adalah "Thobarisy, Al-Imam Asy-Syaikh Abi Aly Al-Fadl bin Al-Hasan bin Al-Fadl Ath. 1998. Majma Al-Bayan fi Tafsiril Qur'an. Bairut Libanon: Darul Kutub Al-Ilmiyyah. (5) Al-Mizan fi tafsiri'l-Qur'an, atau lebih dikenal dengan Tafsir al-Mizan ditulis oleh cendekiawan Syiah, Muhammad Husain Thabathaba'i wafat 1981 M). Sumber kitab yang digunakan "Thobatobai, Al-Alamah Syayid Muhammad Husain. 1991. Al Mizan fi Tafsiril Qur'an. Beirut, Libanon: Muassatul 'alamy." (6) Tafsir al-Karim ar-Rahman Fi Tafsir Kalam alMannan karya syaikh Abdurrahman bin Nashir as-Sa'di (wafat 1956 M). Tafsir ini bergaya bahasa yang sederhana dan jelas yang dapat langsung dimengerti oleh orang yang berilmu maupun yang bodoh. Dinilai para ulama sebagai tafsir beraliran Wahabi. Kitab yang digunakan adalah "Sa' dy, Al-Allamah as-Syaikh Abdurrahman bin Nashir As. 2003. Tafsirul al-Karim Ar-Rahman fi Tafsir Kalam Al-Mannan. Riyadh: Maktabatur Rusyd." (7) Kitab Tafsiru Aisarut Tafasir oleh Abu Bakar Al Jazairi. Al-Jazairi adalah Ulama Madinah yang mengajar di Universiti Islam Madinah. Dilahirkan pada tahun 1921 dan wafat 1999; (8) Data sekunder penelitian ini adalah pendapat para ulama lainnya yang membahas tentang ayat Rahmatan lil 'Alamin, dan penilaian terhadap sumber primer di atas.

Data yang terkumpul kemudian dilakukan pengolahan data dengan menggunakan cara sebagai berikut analisis isi. Sebagaimana Noeng Muhadjir berpendapat, penelitian ini dianalisis secara objektif, sistematis, dan general. ${ }^{2}$

2 Noeng Muhajir. Metodologi Penelitian Kualitatif, edisi ke-III, Cet. Ke-7. (Yogyakarta: 
Pendekatan yang digunakan adalah komparatif antara hasil penafsiran ulamaulama pada aliran-aliran dalam Islam.

\section{Tafsir Ayat Rahmatan lil 'Alamin Menurut Penafsir Ahlu Sunnah, Muktazilah, Syiah, dan Wahabi}

Dari hasil studi pustaka terhadap karya para ulama Ahlu Sunnah Ahlu Sunnah, Muktazilah, Syiah, dan Wahabi didapatkan penafsiran sebagai berikut:

1. Tafsir Ayat Rahmatan lil ‘Alamin Oleh Penafsir Ahlu Sunnah

a. Tafsir ayat Rahmatan lil 'Alamin dalam Kitab Mafatih al-Ghoib karya Fakhruddin ar-Razi (544-606 H). ${ }^{3}$

Ar-Razi dinilai oleh para ulama sebagai penafsir beraliran Ahlu Sunnah ini menyatakan bahwa Rahmatan lil 'Alamin adalah sebagai berikut: "Dalam ayat Rahmatan lil 'Alamin sesungguhnya Rasulullah SAW adalah rahmah di bidang agama dan dunia. Adapun di bidang agama, sesungguhnya Rasulullah SAW diutus saat manusia dalam keadaan jahiliyyah dan tersesat, dan para ahli kitab berada dalam kebingungan tentang masalah mereka karena panjangnya kejumudan dan terputusnya kemutawatiran mereka, dan terjadinya perbedaan dalam kitab mereka. Dalam keadaan seperti itulah AllahSWT mengutus Rasulullah SAW: saat tidak ada jalan bagi para pencari kebenaran menuju kesuksesan dan kebahagiaan (pahala); Nabi mengajak mereka kepada jalan kebenaran dan menjelaskan kepada mereka jalan menuju kebahagiaan (pahala); Nabi menjelaskan syariah dan menjelaskan perbedaan halal dan haram. Para pencari kebenaranlah yang bisa mengambil manfaat rahmatan lil alamin. Rahmah tidak bisa dirasakan para ahli taqlid, para penentang kebenaran, dan orang-orang yang sombong. Para pencari kebenaranlah yang mendapat pertolongan dari Allah SWT. Sebagaiman Allah SWT menjelaskan dalam Surat Fushshilat ayat 44 :

Rake Surasin, 1996), hal. 69.

3 Al-Imam Muhammad Fakhruddin Ibnu Al-Allamah Dliyauddin Umar, Al-Tafsir AlFakhur Razi Juz 23, (Beirut: Darul Fikr, 1981), hal. 230-231. 
"Dan jikalau Kami jadikan Al Quran itu suatu bacaan dalam bahasa selain Arab, tentulah mereka mengatakan: "Mengapa tidak dijelaskan ayatayatnya?" Apakah (patut Al Quran) dalam bahasa asing sedang (rasul adalah orang) Arab? Katakanlah: "Al Quran itu adalah petunjuk dan penawar bagi orang-orang mukmin. Dan orang-orang yang tidak beriman pada telinga mereka ada sumbatan, sedang Al Quran itu suatu kegelapan bagi mereka. Mereka itu adalah (seperti) yang dipanggil dari tempat yang jauh." (QS. Fushshilat: 44).

Diduniaini, dengan sebab Rahmatan lil 'Alamin, manusia dibersihkan dari kehinaan, pembunuhan (pertentangan), dan peperangan. Lalu bagaimana disebut rahmah, padahal Rasulullah juga berperang dan mengambil rampasan perang dan zakat? Argumen yang Pertama, Rasulullah memerangi kaum yang sombong, menentang, tidak mau berpikir dan mengambil pelajaran. Sebagaimana Allah SWT bersifat rahman rahim, namun Allah SWT juga menghukum orang-orang yang bermaksiat. Sebagaimana Firman Allah SWT: "Dan Kami turunkan dari langit air yang banyak manfaatnya lalu Kami tumbuhkan dengan air itu pohon-pohon dan biji-biji tanaman yang diketam." (QS. Qaf: 9) Kemudian hujan tersebut dapat menjadi sebab kerusakan. Kedua, umat nabi-nabi terdahulu segera dihancurkan oleh Allah SWT begitu mendustakan nabi Allah SWT, namun umat nabi Muhammad SAW diberikan tangguh untuk memperbaiki diri sampai kematian mereka atau sampai kiamat datang. Sebagaimana firman Allah SWT:

"Dan Allah sekali-kali tidak akan mengazab mereka, sedang kamu berada di antara mereka. Dan tidaklah (pula) Allah akan mengazab mereka, sedang mereka meminta ampun." (QS. Al-Anfal: 33).

Tidak dikatakan apakah sesungguhnya Allah SWT berfirman:

"Perangilah mereka, niscaya Allah akan menghancurkan mereka dengan (perantaraan) tangan-tanganmu dan Allah akan menghinakan mereka dan menolong kamu terhadap mereka, serta melegakan hati orang-orang yang beriman." (QS. At-Taubah: 14). 
Dan Allah SWT berfirman:

"Sehingga Allah mengazab orang-orang munafik laki-laki dan perempuan dan orang-orang musyrikin laki-laki dan perempuan; dan sehingga Allah menerima taubat orang-orang mukmin laki-laki dan perempuan. Dan adalah Allah Maha Pengampun lagi Maha Penyayang." (QS. Al-Ahzab: 73).

Yang ketiga, Sesungguhnya Nabi Muhammad SAW adalah pribadi yang dalam kondisi puncak Akhlah yang Baik. Sebagaimana firman Allah SWT: "Dan sesungguhnya kamu benar-benar berbudi pekerti yang agung." (QS. Al-Qolam: 4). Terkait dengan hal ini sebauh hadis yang diriwayatkan oleh Abu Hurairah RA: "Seseorang meminta kepada Rasulullah SAW, wahai Rasulullah laknatlah orang-orang musyrikin." Rasulullah SAW menjawab, "Sesungguhnya aku diutus sebagai rahmat, dan aku tidak diutus sebagai pengazab." Dalam riwayat Hudzaifah disebutkan, "Sesungguhnya aku adalah manusia yang bisa marah sebagaimana manusia lainnya, mungkin satu saat ada seseorang yang aku cela atau aku melaknatnya,mudah-mudahan hal tersebut menjadi rahmat baginya kelak di hari kiamat."

Yang keempat: Abdurrahman bin Zaid berpendapat Ayat "Dan tiadalah Kami mengutus kamu, melainkan untuk (menjadi) rahmat bagi semesta alam." Yang dimaksud adalah khusus kaum mukminin. Imam Abu Al-Qosim Al-Ansori berpendapat bahwa kedua pendapat di atas merujuk pada makna yang satu. Saat kami menjelaskan bahwa Rasulullah Saw adalah rahmat bagi semuanya, maka pemikiran dalam ayat Allah dan ayat Rasulullah, adapun yang berpaling dan menolak, maka akan terjadi kegoncangan dalam dirinya sebagaimana Firman Allah SWT: sedang Al Quran itu suatu kegelapan bagi mereka.

b. Tafsir ayat Rahmatan lil 'Alamin dalam KitabFathu al-Qodir karya Imam As Syaukani $(1173-1250 \mathrm{H}){ }^{4}$

Dalam kitab ini Asy-Syaukani berpendapat bahwa makna ayat rahmatan lil 'alamin adalah tidaklah Kami mengutusmu, wahai

4 Al-Imam Muhammad bin Aly bin Muhammad Asy Syaukany, Fathul Qodir, (2003). Diakses melalui www.altafsir.com tanggal 20 Januari 2016. 
Muhammad, dengan membawa hukum-hukum syariat, melainkan sebagai rahmat bagi seluruh manusia tanpa ada keadaan atau alasan khusus yang menjadi pengecualian. Satu-satunya alasan Kami mengutusmu, wahai Muhammad, adalah sebagai rahmat yang luas. Karena kami mengutusmu dengan membawa sesuatu yang menjadi sebab kebahagiaan di dunia dan akhirat'. Adapun makna rahmat bagi orang kafir adalah sesungguhnya mereka beriman kepada Nabi Muhammad sebagian dari perilaku merendahkan, memburukkan, dan terlepas dari keimanan. Yang dimaksud dengan alam semesta adalah mukmin secara khusus. Maka pendapat yang pertama lebih utama dengan dalil Firman Allah SWT: "Dan Allah sekali-kali tidak akan mengazab mereka, sedang kamu berada di antara mereka. Dan tidaklah (pula) Allah akan mengazab mereka, sedang mereka meminta ampun." (QS. Al-Anfal: 33). Kemudian Allah SWT menjelaskan bahwa hakikat asal dari rahmah adalah tauhid dan terbebas dari kesyirikan.

c. Muhammad bin Ahmad Al-Qurthubi dalam Tafsir Al-Qurthubi ${ }^{5}$

Al-Qurthubi menjelaskan bahwa Said bin Jubair berkata: dari Ibnu Abbas, beliau berkata: "Muhammad SAW adalah rahmat bagi seluruh manusia. Bagi yang beriman dan membenarkan ajaran beliau, akan mendapat kebahagiaan. Bagi yang tidak beriman kepada beliau, diselamatkan dari bencana yang menimpa umat terdahulu berupa ditenggelamkan ke dalam bumi atau ditenggelamkan dengan air." Ibnu Zaid berpendapat bahwa 'seluruh alam' dalam ayat ini adalah hanya orang-orang yang beriman".

2. Tafsir Ayat Rahmatan lil 'Alamin Oleh Penafsir Muktazilah'

Tafsir Ayat Rahmatan lil 'Alamin menurut Kitab Al-Kasysyaaf'An Haqaa'iq at-Tanziil Wa 'Uyuun al-Aqaawiil Fii Wujuuh at-Ta'wiil karya Abu al-Qasim, Mahmud bin`Umar bin Muhammad al-Khawarizmi. Dalam tafsir Al-Kasyaf

5 Abi Abdillah Muhammad bin Ahmad Al-Anshory alQurthuby. Al-Jami Al-Ahkamil Qur'an. (Beirut: Ar-Resalah Publisers, 2006), hal. 302-303.

6 Az-Zamakhsari, Al-Allamah Jarul Qasim Mahmud bin Umar Al-Kasysyaaf 'An Haqaa'iq at-Tanziil Wa 'Uyuun al-Aqaawiil Fii Wujuuh at-Ta'wiil Juz 4. (Riyadl: Al-Abikan, 1998), hal.170 
ini disebutkan:Nabi Muhammad SAW diutus sebagai rahmat alam semesta, karena sesungguhnya beliau datang dengan yang membahagiakan bagi yang mengikutinya. Dan siapa yang menyelisihi dan tidak mengikutinya, maka hal itu datang dari nafsunya yang menyempitkan bagiannya dari rahmat. Misalnya Allah mengalirkan air yang deras. Manusia menyirami tanaman dan lainnya dengan air tersebut, kemudian mereka merusaknya, dan tinggallah manusia berlebih-lebihan dengan penggunaannya, maka menjadi sempitlah keadaan mereka. Sumber air keluar memancar dengan sendirinya adalah nikmat dari Allah SWT yang takut kepadanya. Tetapi orang yang malas, adalah menghianati dirinya sendiri. Dengan haramnya nikmat atas dirinya. Rahmat bagi orang-orang yang durhaka adalah diakhirkannya siksa bagi mereka.

3. Tafsir Ayat Rahmatan lil 'Alamin Oleh Penafsir Syiah

a. Tafsir Ayat Rahmatan lil 'Alamin menurut Kitab Majma' al-Bayan fi Tafsir al-Qur' an disusun oleh Abu Ali al-Fadll bin al-Hasan ai-Thabarisi (wafat $548 \mathrm{H}$ ). ${ }^{7}$

Dalam kitab Majma Al-Bayan ini disebutkan bahwa:Aku tidak mengutusmu wahai muhammad (kecuali untuk menjadi rahmatan lil alamin) yaitu kenikmatan bagi mereka. Ibn Abbas berpendapat: rahmat bagi yang berbuat baik maupun yg fasik, bagi orang mukmin dan orang kafir. Yakni nikmat di dunia dan akhirat bagi orang mukmin dan rahmat bagi orang kafir di dunia. Rahmat bagi orang kafir dengan dimaafkan dari yg menimpa umat terdahulu. Diriwayatkan bahwa sesungguhnya Nabi SAW bertanya kepada malaikat jibril ketika turun ayat ini: "Apakah ada sesuatu yg menimpamu dari rahmat ini?" Berkata Jibril AS: “Ya, sesungguhnya aku menjadi kagum, maka aku beriman kepadamu ketika Allah memujiku dengan firmannya di dalam al-Quran. "Yang mempunyai kekuatan, dan mempunyai kedudukan tinggi di sisi Allah" (At-takwir: 20). Dan sungguh telah bersabda Nabi SAW: "sesungguhnya aku adalah rahmat yang dihadiahkan". Dan dikatakan: "Sesungguhnya pandangan tersebut di dalam nikmat yg

7 Al-Imam Asy-Syaikh Abi Aly Al-Fadl bin Al-Hasan bin Al-Fadl AthThobarisy, Majma Al-Bayan fi Tafsiril Qur'an. Jilid 7. (Bairut Libanon: Darul Kutub Al-Ilmiyyah, 1998), hal. 95. 
diberikan atas orang kafir. Sesungguhnya Allah menunnjukkan kepada orang kafir untuk beriman dan memberinya petunjuk dan orang kafir tidak menemukannya. Seperti halnya disuguhkannya makanan pada orang yang lapar, tapi dia tidak memakannya. Sesungguhnya Allah pemberi nikmat kepada mereka dan mereka tidak menerimanya. Dan di dalam ayat tersebut ada dilalah yg menunjukkan terhadap batalnya perkataan ahli jabariyah di dalam menafsirkan bahwasanya Allah tidak memberikan nikmat atas orang kafir karena Allah S.W.T menjelaskan ketika mengutus Nabi S.A.W sebagai nikmat bagi alam semesta dan bagi setiap orang yg beliau diutus kepada mereka.

b. Al-Mizan fi tafsiri'l-Qur'an, atau lebih dikenal dengan Tafsir al-Mizan ditulis oleh cendekiawan Syiah, Muhammad Husain Thabathaba'i wafat $1981 \mathrm{M}){ }^{8}$

MuhammadHusain Thabathaba'iberpendapat bahwa:Sesungguhnya engkau rahmat yg diutus kepada semua golongan manusia. Argumennya adalah huruf lam jamil muhalla, dan hal itu menunjukkan keumuman kerasulan. Beliau RasulullahSAW rahmat kepada dunia, dari sisi kerasulan beliau, mereka yang mengambilnya sebagai agama dari beliau, dengan hal itu penduduk dunia akan dikarunia kebahagiaan dunia dan akhirat mereka. Beliau Rasulullah SAW kepada duduk dunia, dari sisibeliau membawa kebaikan dengan dakwah beliau.

\section{Tafsir Ayat Rahmatan lil ‘Alamin Oleh Penafsir Wahabi}

a. Tafsir al-Karim ar-Rahman Fi Tafsir Kalam al-Mannan karya syaikh Abdurrahman bin Nashir as-Sa' di (wafat 1956 M). ${ }^{9}$

As-Sa' diberpendapatbahwa:Yangmaksudnyabahwaayatrahmatan lil 'alamin adalah rahmah yang dihadiahkan kepada hamba-hamba Allah SWT. Orang mukmin menerima rahmat ini, mensyukurinya dan menjaganya. Selain orang mukmin berarti mengingkari nikmat ini dan menggantinya dengan kekafiran, mereka menolak rahmat dan nikmat Allah SWT.

8 Thobatobai, Al-Alamah Syayid Muhammad Husain. Al Mizan fi Tafsiril Qur'an. (diakses melalui www.altafsir.com tanggal 21 Januari 2016.

9 Al-Allamah As-Syaikh Abdurrahman bin Nashir As Sa'dy, Tafsirul al-Karim ArRahman fi Tafsir Kalam Al-Mannan. (Tanpa Kota: Muassasah Ar-Risalah, 2000), hal 1/352. 
b. Kitab Tafsiru Aisarut Tafasir oleh Abu Bakar Al Jazairi. Al-Jazairi adalah Ulama Madinah yang mengajar di Universiti Islam Madinah. Dilahirkan pada tahun 1921 dan wafat 1999.

Aljazairi berpendapat bahwa ayat rahmatan lil 'alamin adalah rahmat bagi manusia dan jin yang mukmin ataupun yang kafir. Mukmin mendapatkan rahmat dengan mengikuti Rasulullah SAW dan mendapatkan surga Allah SWT sebab rahmatnya. Kafir diakhirkan adzabnya.

c. Ibnu Qayyim Al Jauziyyah dalam Tafsir Ibnul Qayyim ${ }^{10}$

Pendapat yang lebih benar dalam menafsirkan ayat ini adalah bahwa rahmat disini bersifat umum. Dalam masalah ini, terdapat dua penafsiran: Pertama: Alam semesta secara umum mendapat manfaat dengan diutusnya Nabi Muhammad SAW. Orang yang mengikuti beliau, dapat meraih kemuliaan di dunia dan akhirat sekaligus. Orang kafir yang memerangi beliau, manfaat yang mereka dapatkan adalah disegerakannya pembunuhan dan maut bagi mereka, itu lebih baik bagi mereka. Karena hidup mereka hanya akan menambah kepedihan adzab kelak di akhirat. Kebinasaan telah ditetapkan bagi mereka. Sehingga, dipercepatnya ajal lebih bermanfaat bagi mereka daripada hidup menetap dalam kekafiran.

Orang kafir yang terikat perjanjian dengan beliau, manfaat bagi mereka adalah dibiarkan hidup didunia dalam perlindungan dan perjanjian. Mereka ini lebih sedikit keburukannya daripada orang kafir yang memerangi Nabi Shallallahu 'alaihi Wa sallam. Orang munafik, yang menampakkan iman secara zhahir saja, mereka mendapat manfaat berupa terjaganya darah, harta, keluarga dan kehormatan mereka. Mereka pun diperlakukan sebagaimana kaum muslimin yang lain dalam hukum waris dan hukum yang lain. Dan pada umat manusia setelah beliau diutus, Allah Ta'ala tidak memberikan adzab yang menyeluruh dari umat manusia di bumi. Kesimpulannya, semua manusia mendapat manfaat dari diutusnya Nabi Shallallahu 'alaihi Wa sallam.

${ }^{10}$ Ibnu Qoyyim Al-Jauziyah. Tafsir Ibnu Qayyim, terjemahan Indonesia Kathur Suhardi. (Jakarta Timur: Darul Falah, 2000), hal 428-429. 
Kedua: Islam adalah rahmat bagi setiap manusia, namun orang yang beriman menerima rahmat ini dan mendapatkan manfaat di dunia dan di akhirat. Sedangkan orang kafir menolaknya. Sehingga bagi orang kafir, Islam tetap dikatakan rahmat bagi mereka, namun mereka enggan menerima. Sebagaimana jika dikatakan 'Ini adalah obat bagi si fulan yang sakit'. Andaikan fulan tidak meminumnya, obat tersebut tetaplah dikatakan obat"

5. Tafsir yang Dirujuk banyak tafsir lainnya dari penafsir aliran Islam

a. Tafsir Ayat Rahmatan lil 'Alamin menurut Muhammad bin Jarir Ath Thabari dalam Tafsir Ath-Thabari ${ }^{11}$

Dalam tafsir Ath-Thobari didapatkan pendapat bahwa rahmatan lil 'alamin adalah penyebutan Allah SWT kepada Nabi Muhammad SAW sebagai rahmat bagi mahluk Allah SWT. Kemudian para ahli takwil berbeda pendapat: Apakah seluruh alam yang dimaksud dalam ayat ini adalah seluruh manusia baik mukmin dan kafir? Ataukah hanya manusia mukmin saja? Sebagian ahli takwil berpendapat, yang dimaksud adalah seluruh manusia baik mu'min maupun kafir. Mereka mendasarinya dengan riwayat dari Ibnu Abbas RA. dalam menafsirkan ayat ini: "Siapa saja yang beriman kepada Allah dan hari akhir, ditetapkan baginya rahmat di dunia dan akhirat. Namun siapa saja yang tidak beriman kepada Allah dan Rasul-Nya, bentuk rahmat bagi mereka adalah dengan tidak ditimpa musibah yang menimpa umat terdahulu, seperti mereka semua di tenggelamkan atau ditimpa gelombang besar." Dalam riwayat yang lain: "Rahmat yang sempurna di dunia dan akhirat bagi orang-orang yang beriman kepada Rasulullah. Sedangkan bagi orang-orang yang enggan beriman, bentuk rahmat bagi mereka adalah dengan tidak ditimpa musibah yang menimpa umat terdahulu."

Ahli takwil lainnya berpendapat: Pendapat ahli tafsir yang lain mengatakan bahwa yang dimaksud adalah orang-orang beriman saja. Mereka membawakan riwayat dari Ibnu Zaid dalam menafsirkan

11 Abi Jakfar Muhammad Jarir AthThobari,Tafsir Ath-Thobary: Jamiul Bayan 'an Ta'wil Al-Qur'an Juz 16. (Jizah: Dar Al-Hajar, 2001), hal. 440. 
ayat ini: "Dengan diutusnya Rasulullah, ada manusia yang mendapat bencana, ada yang mendapat rahmah, walaupun bentuk penyebutan dalam ayat ini sifatnya umum, yaitu sebagai rahmat bagi seluruh manusia. Seluruh manusia yang dimaksud di sini adalah orangorang yang beriman kepada Rasulullah, membenarkannya dan menaatinya."

Pendapat yang paling benar di antara keduanya adalah pendapat yang pertama, sebagaimana riwayat Ibnu Abbas. Yaitu Allah mengutus Nabi Muhammad SAW sebagai rahmat bagi seluruh manusia, baik mu'min maupun kafir. Rahmat bagi orang mu'min yaitu Allah memberinya petunjuk dengan sebab diutusnya Rasulullah SAW. Beliau SAW memasukkan orang-orang beriman ke dalam surga dengan iman dan amal mereka terhadap ajaran Allah. Sedangkan rahmat bagi orang kafir, berupa tidak disegerakannya bencana yang menimpa umat-umat terdahulu yang mengingkari ajaran Allah."

b. Tafsir Ayat Rahmatan lil 'Alamin menurut Ibnu Katsir dalam Kitab tafsir Ibnu Katsir ${ }^{12}$

Ayat Rahmatan lil 'Alamin adalah Allah SWT mengabarkan bahwa Dia telah menjadikan Muhammad sebagai rahmat bagi semesta alam. Yaitu, Dia mengutusnya sebagai rahmat untuk kalian semua. Barangsiapa yang menerima rahmat dan mensyukuri nikmat ini, niscaya dia akan berbahagia di dunia dan di akhirat. Barangsiapa yang menolak dan menentangnya, niscaya dia akan merugi di dunia dan di akhirat. Imam Muslim di dalam Shahihnya meriwayatkan bahwa Abu Hurairah berkata: "Ya Rasulallah! Sumpahilah orang-orang musyrik itu." Beliau ber-sabda: “Sesungguhnya Aku tidak diutus sebagai orang yang melaknat. Aku diutus hanyalah sebagai rahmat." (HR. Muslim). Dari Ibnu 'Abbas: Dan tiadalah Kami mengutusmu, melainkan untuk (menjadi) rahmat bagi semesta alam adalah Barangsiapa yang mengikutinya, niscaya hal itu menjadi rahmat di dunia dan di akhirat. Dan barangsiapa yang tidak mengikutinya, niscaya dia akan ditimpa suatu ujian yang mengenai seluruh umat berupa bencana alam,

12 Al-Imam Al-Jalil al-Hafidz Imaduddin Abi Fida' Ismail bin Katsir ad-DimasyqiKatsir, Tafsir Al-Qur'anul Adzim. (Jizah: Maktabah Aulad As-Syaik At-Turats, 2000), hal. 458-461. 
perubahan bentuk dan fitnah.” Allah SWT berfirmah: “Tidakkah kamu perhatikan orang-orang yang telah menukar nikmat Allah (perintahperintah dan ajaran-ajaran Allah) dengan kekafiran dan menjatuhkan kaumnya ke lembah kebinasaan? Yaitu neraka jahannam; mereka masuk kedalamnya; dan itulah seburuk-buruk tempat kediaman." (QS. Ibrahim:28-29). Dan Allah SWT befirman dalam Al Qur'an: "Katakanlah: "Al Quraan itu adalah petunjuk dan penawar bagi orang-orang mukmin. Dan orang-orang yang tidak beriman pada telinga mereka ada sumbatan, sedang Al Quraan itu suatu kegelapan bagi mereka (tidak memberi petunjuk bagi mereka). Mereka itu adalah (seperti) yang dipanggil dari tempat yang jauh." (QS. Fushshilat: 44).

\section{Pembahasan}

Penelitian memetakan pembahasan tafsir ayat Rahmatan lil 'Alamin ini menjadi 5 (lima): (1) Aspek-aspek yang dibahas dalam penafsiran (2) Asbabun Nuzul; (3) Makna Rahmat; (4) Makna Alamin; (5) kontekstualisasi dalam kehidupan. Perlu ditegaskan bahwa pembahasan ini adalah pembahasan tentang tafsir yang dilakukan oleh para penafsir, yan artinya peneliti tidak melakukan penafsiran secara langsung terhadap ayat Al-Qur'an.

Dari semua penafsiran aliran yang berbeda: Ahlu Sunnah, Muktazila, Syiah, dan Wahabi, bahwa aspek yang dibahas adalah sama, yaitu (1) makna rahmat dan (2) makna alamin (alam semesta). Makna rahmat dibahas lebih detail oleh Aliran Ahlu Sunnah, dengan membahas apakah aspek itu agama saja atau lainnya. Begitu juga pembahasan tentang aspek alamin ini juga lebih mendetail sampai pada pembahasan apakah 'alamin termasuk didalamnya para malaikat. Pembahasan Ahlu Sunnah juga meliputi pembahasan dengan metode ilmu kalam, yang ini tidak dilakukan oleh aliran lainnya.

Semua aliran tidak ada yang mengemukakan asbabun nuzul ayat ini, hanya aliran Ahlu Sunnah ${ }^{13}$ mengemukakan beberapa hadis yang mempunyai konteks terhadap ayat ini, seperti: pertama, dari Abu Hurairah RA. berkata, bahwa telah dikatakan, "Wahai Rasulullah, berdoalah melaknat kaum Musyrikin.” Beliau berkata: "Saya tidak dikirim sebagai kutukan, melainkan sebagai rahmat." 
Kedua, Imam Ahmad meriwayatkan bahwa 'Amr bin Abi Qurrah Al-Kindi berkata: "Hudzaifah RA ada di Al-Mada'in dan dia menyebutkan sesuatu, bahwa Rasulullah SAW telah bersabda. Hudzaifah datang ke Salman RA dan Salman RA berkata: 'Ya, Hudzaifah, Rasulullah SAW kadang-kadang marah dan berbicara dalam kondisi demikian, dan kadang-kadang senang dan berbicara dalam kondisi demikian. Saya tahu bahwa Rasulullah SAW telah menyapa kami dan berkata: “Sebagian umatku telah aku cerca atau aku maki ketika aku marah, karena aku adalah salah seorang dari keturunan Adam, dan aku bisa menjadi marah seperti dirimu. Tetapi Allah SAW telah mengirimku sebagai rahmat untuk seluruh alam, sehingga aku akan membuat itu (marahku) sebagai berkah buatnya di hari kebangkitan."

Makna rahmat dimaknai berbeda. Perbedaannya terletak pada fokus pembahasan bahwa rahmat itu adalah terbebas dari kesyirikan atau pengakhiran siksa bagi orang-orang kafir. Yang menarik adalah pendapat Ibnu Qoyyum Jauziyah yang berpendapat bahwa rahmat bagi orang kafir yang memusuhi Islam adalah disegerakannya pembunuhan dan maut bagi mereka, itu lebih baik bagi mereka. Karena hidup mereka hanya akan menambah kepedihan adzab kelak di akhirat. Kebinasaan telah ditetapkan bagi mereka. Sehingga, dipercepatnya ajal lebih bermanfaat bagi mereka daripada hidup menetap dalam kekafiran.

Senada dengan Ibnu Qoyyum adalah pendapat aliran Syiah bahwa sesungguhnya Allah SWT menunnjukkan kepada orang kafir untuk beriman dan memberinya petunjuk dan orang kafir tidak menemukannya. Seperti halnya disuguhkannya makanan pada orang yang lapar, tapi dia tidak memakannya. Sesungguhnya Allah pemberi nikmat kepada mereka dan mereka tidak menerimanya. Dan di dalam ayat tersebut ada dilalah yg menunjukkan terhadap batalnya perkataan ahli jabariyah di dalam menafsirkan bahwasanya Allah tidak memberikan nikmat atas orang kafir karena Allah SWT menjelaskan ketika mengutus Nabi SAWsebagai nikmat bagi alam semesta dan bagi setiap orang yg beliau diutus kepada mereka.

Aliran Ahlu Sunnah lebih moderat dalam penafsiran tentang rahmat ini denganmendasarinya dengan riwayat dari Ibnu Abbas RA. dalam menafsirkan ayat ini: "Siapa saja yang beriman kepada Allah dan hari akhir, ditetapkan baginya rahmat di dunia dan akhirat. Namun siapa saja yang tidak beriman 
kepada Allah dan Rasul-Nya, bentuk rahmat bagi mereka adalah dengan tidak ditimpa musibah yang menimpa umat terdahulu, seperti mereka semua di tenggelamkan atau ditimpa gelombang besar." Dalam riwayat yang lain: "Rahmat yang sempurna di dunia dan akhirat bagi orang-orang yang beriman kepada Rasulullah. Sedangkan bagi orang-orang yang enggan beriman, bentuk rahmat bagi mereka adalah dengan tidak ditimpa musibah yang menimpa umat terdahulu."

Makna alamin menurut aliran-aliran ini meliputi: (1) manusia dan jin yang mukmin ataupun yang kafir; (2) orang mukmin saja; (3) orang mukmin dan orang kafir menolak rahmat; (4) apapun yang ada di muka bumi.

Perbedaan mendasar dari Ahlu Sunnah, Muktazilah, Syiah, dan Wahabi dalam menafsirkan ayat rahmatan lil 'alamin adalah memaknai rahmat. Perbedaannya terletak pada fokus pembahasan bahwa rahmat itu adalah terbebas dari kesyirikan atau pengakhiran siksa bagi orang-orang kafir. Yang menarik adalah pendapat Ibnu Qoyyum Jauziyah yang dijadikan salah satu pegangan bagi Wahabi yang berpendapat bahwa rahmat bagi orang kafir adalah disegerakannya pembunuhan dan maut bagi mereka, itu lebih baik bagi mereka. Karena hidup mereka hanya akan menambah kepedihan adzab kelak di akhirat. Kebinasaan telah ditetapkan bagi mereka. Sehingga, dipercepatnya ajal lebih bermanfaat bagi mereka daripada hidup menetap dalam kekafiran. Secara hakiki penafsiran Ibnu Qoyyum ini adalah benar, namun mempunyai benturan dengan surat al-Kafirun maupun fase-fase dakwah bilhikmah dan berargumen serta bersatunya umat muslim yang dipimpin oleh Rasulullah SAW di Madinah, dengan piagam madinahnya.

Syiah lebih sedikit lunak dengan pendapat yang mengemukakan bahwa sesungguhnya Allah SWT menunnjukkan kepada orang kafir untuk beriman dan memberinya petunjuk dan orang kafir tidak menemukannya. Seperti halnya disuguhkannya makanan pada orang yang lapar, tapi dia tidak memakannya. Sesungguhnya Allah pemberi nikmat kepada mereka dan mereka tidak menerimanya. Dan di dalam ayat tersebut ada dilalah yg menunjukkan terhadap batalnya perkataan ahli jabariyah di dalam menafsirkan bahwasanya Allah tidak memberikan nikmat atas orang kafir karena Allah S.W.T menjelaskan ketika mengutus Nabi S.A.W sebagai nikmat bagi alam semesta dan bagi setiap orang yg beliau diutus kepada mereka. 
Aliran Ahlu Sunnah lebih moderat dalam penafsiran tentang rahmat ini denganmendasarinya dengan riwayat dari Ibnu Abbas RA. dalam menafsirkan ayat ini: "Siapa saja yang beriman kepada Allah dan hari akhir, ditetapkan baginya rahmat di dunia dan akhirat. Namun siapa saja yang tidak beriman kepada Allah dan Rasul-Nya, bentuk rahmat bagi mereka adalah dengan tidak ditimpa musibah yang menimpa umat terdahulu, seperti mereka semua di tenggelamkan atau ditimpa gelombang besar." Dalam riwayat yang lain: "Rahmat yang sempurna di dunia dan akhirat bagi orang-orang yang beriman kepada Rasulullah. Sedangkan bagi orang-orang yang enggan beriman, bentuk rahmat bagi mereka adalah dengan tidak ditimpa musibah yang menimpa umat terdahulu."

\section{E. Penutup}

Aliran Ahlu Sunnah lebih moderat dalam penafsiran ayat ini bahwa yang beriman kepada Allah SWT, maka dianugerahkan rahmat di dunia dan akhirat. Bagi yang tidak beriman kepada Allah SWT, maka bentuk rahmatnya adalah dengan tidak disegerakannya musibah di dunia sebagaimana umat-umat terdahulu.Sedangkantafsir Muktazilah bercorak rasional dengan argumen yang bagus, dan kekafiran diumpamakan sebagai kesalahan sendiri, yang tidak harus dihukum, karena pada dasarnya kekafiran adalah hukuman itu sendiri. Kemudian tafsir Syiah, bahwa rahmat bagi yang berbuat baik maupun yg fasik, bagi orang mukmin dan orang kafir. Yakni nikmat di dunia dan akhirat bagi orang mukmin dan rahmat bagi orang kafir di dunia. Rahmat bagi orang kafir dengan dimaafkan dari yg menimpa umat terdahulu. Orang kafir diperintah beriman dan Allah SWT memberinya petunjuk, namun orang kafir tidak menemukannya.

Selanjutnya, penafsir yang diikuti aliran Wahabi adalah yang cenderung secara eksplisit berwatak keras terhadap orang yang tidak beriman. Penafsir yang diikuti aliran Wahabi berpendapat bahwa rahmat bagi orang kafir yang memusuhi Islam adalah disegerakannya pembunuhan dan kematian bagi mereka, dan hal itu lebih baik bagi mereka. Karena dengan tidak beriman dan permusuhan mereka hanya akan melipatkan adzab di akhirat.

Terdapat Perbedaan mendasar dari Ahlu Sunnah, Muktazilah, Syiah, dan Wahabi dalam menafsirkan ayat rahmatan lil ‘alamin adalah memaknai rahmat. 
Perbedaannya terletakpada fokus pembahasan bahwa rahmat itu adalah terbebas dari kesyirikan atau pengakhiran siksa bagi orang-orang kafir. Yang menarik adalah pendapat Ibnu Qoyyum Jauziyah yang dijadikan salah satu pegangan bagi Wahabi yang berpendapat bahwa rahmat bagi orang kafir yang memusuhi Islam adalah disegerakannya pembunuhan dan maut bagi mereka, itu lebih baik bagi mereka. Karena hidup mereka hanya akan menambah kepedihan adzab kelak di akhirat. Kebinasaan telah ditetapkan bagi mereka. Sehingga, dipercepatnya ajal lebih bermanfaat bagi mereka daripada hidup menetap dalam kekafiran. Secara hakiki penafsiran Ibnu Qoyyum ini adalah benar, namun mempunyai benturan dengan surat al-Kafirun maupun fasefase dakwah bilhikmah dan berargumen serta bersatunya umat muslim yang dipimpin oleh Rasulullah SAW di Madinah, dengan piagam madinahnya.

Syiah lebih sedikit lunak dengan pendapat yang mengemukakan bahwa sesungguhnya Allah SWT menunnjukkan kepada orang kafir untuk beriman dan memberinya petunjuk dan orang kafir tidak menemukannya. Seperti halnya disuguhkannya makanan pada orang yang lapar, tapi dia tidak memakannya. Sesungguhnya Allah pemberi nikmat kepada mereka dan mereka tidak menerimanya. Dan di dalam ayat tersebut ada dilalah yg menunjukkan terhadap batalnya perkataan ahli Jabariyah di dalam menafsirkan bahwasanya Allah tidak memberikan nikmat atas orang kafir karena Allah SWT menjelaskan ketika mengutus Nabi SAW sebagai nikmat bagi alam semesta dan bagi setiap orang yg beliau diutus kepada mereka.

Aliran Ahlu Sunnah lebih moderat dalam penafsiran tentang rahmat ini denganmendasarinya dengan riwayat dari Ibnu Abbas RA. dalam menafsirkan ayat ini: "Siapa saja yang beriman kepada Allah dan hari akhir, ditetapkan baginya rahmat di dunia dan akhirat. Namun siapa saja yang tidak beriman kepada Allah dan Rasul-Nya, bentuk rahmat bagi mereka adalah dengan tidak ditimpa musibah yang menimpa umat terdahulu, seperti mereka semua di tenggelamkan atau ditimpa gelombang besar." Dalam riwayat yang lain: "Rahmat yang sempurna di dunia dan akhirat bagi orang-orang yang beriman kepada Rasulullah. Sedangkan bagi orang-orang yang enggan beriman, bentuk rahmat bagi mereka adalah dengan tidak ditimpa musibah yang menimpa umat terdahulu."

Dengan perbedaan penafsiran ini maka sangat mungkin pertikain antar aliran dalam Islam juga disebabkan oleh perbedaan penafsiran ahli tafsirnya. 
Dengankondisi ini, Akademisi dapat melakukan penelitian yang lebih mendetail tentang tema ini, dan dilanjutkan pada perbedaan Aqidah, Fikih, dan Akhlak sebagai penelitian selanjutnya. Sementara itu, Perbedaan penafsiran ini sebenarnya dapat dikatakan saling melengkapi dengan beberapa syarat: (1) yaitu perlunya dijelaskan secara lebih mendetail terhadap penafsiran-penafsiran yang dilakukan oleh Wahabi: dan (2) kondisi-kondisi dimana penerapan penafsiran itu bisa diterapkan atau kontekstual.Wallahu A'lam.

\section{DAFTAR PUSTAKA}

Ahmad bin Muhammad bin Hambal. 1995. Al-Musnad. Darul Hadis AlQohiroh.

Bashri Abi Hasan Ali bin Muhammad bin Habaib Al-Mawardi Al. Tt. AnNukatu wal 'Uyun Tafsir Al-Mawardi. Bairut Libanon: Darul Kutub AlIlmiyyah.

Baidan, Nashiruddin. 1987. Metodelogi Pemafsiran Al-Qur'an. Jakarta: Suryakarsa. Baidan, Nasrudin. 2005. Wawasan Baru Ilmu Tafsir. Yogyakarta: Pustaka Pelajar.

Baidlowy, Imam al-Muhaqqiqin wa Qudwatul al-Mudaqqiqin Al-Qodli Nashir Al-Din Abi Said Abdullah bin Umar bin Muhammad Asy-Syairozu Al. 2003. Tafsir Al-baidlowy. Bairut Libanon: Darul Kutub Al-Ilmiyyah.

Dahlan, Zaini dkk. 1995. Al-Qur'an dan Tafsirnya. Yogyakarta: Universitas Islam Indonesia.

Djalal HA, Abdul. 1990. Urgensi Tafsir Maudu'i Pada Masa Kini. Jakarta: Kalam Mulia.

Dzahabî, Raḩmat Yahya Adz-. Tt. al-Tafsîr wa al-Mufassirûn. Mesir: Dar al-Kutub al'Ilmiyah.

Gulen, Muhammad Fethulleah. 2014. Islam Rahmatan lil Alamin, Menjawab Pertanyaan dan Kebutuhan Manusia Cet. 4. Jakarta: Republika.

Katsir, Al-Imam Al-Jalil al-Hafidz Imaduddin Abi Fida' Ismail bin Katsir adDimasyqi. 2000. Tafsir Al-Qur'anul Adzim. Jizah. Maktabah Aulad AsSyaik At-Turats.

Lohelker, Rudiger. 2015. “Profesor Austria: Islam Indonesia Rahmatan lil 'Alamin. Agama Lain Bagaimana Prof? Dalam Publika News diunduh dari publikanews.com tanggal 30 Oktober 2015. 
Maraghi, Ahmad Musthofa Al. 1989. Terjemah Tafsir Al-Maraghi. Semarang: Toha Putra.

Munawwir, A.W. 1997. Al-Munawwir: Kamus Arab-Indonesia Terlengkap. Surabaya: Pustaka Progressif.

Noeng Muhajir. 1996. Metodologi Penelitian Kualitatif, edisi ke-III, Cet. Ke-7. Yogyakarta: Rake Surasin,

Moleong, Lexy J. 1998. Metode Penelitian Kualitatif. Bandung: Remaja Rosda Karya.

Nadwy, Muhammad Uwais an. 2002. Al-Tafsir Al-Qoyyum lil Imam Ibnu AlQoyyum. Bairut Libanon: Darul Kutub Al-Ilmiyyah.

Nata, Abuddin. 2016. "Islam Rahmatan lil 'Alamin sebagai Model Pendidikan Islam Memasuki Asean Community." Makalah disampaikan pada acara Kuliah Tamu Jurusan Pendidikan Agama Islam Fakultas Ilmu Tarbiyah dan Keguruan UIN Maulana Malik Ibrahim Malang. Senin, 7 Maret 2016.

Razi, Fakhruddin Ar. 1981. Mafatih al-Ghaib. Beirut: Dar al-Fikr.

Samarqondy, Abu Laits Nashr bin Muhammad bin Ahmad bin Ibrahim as. 1993. Tafsir As-Samarqondy Al-Musamma Bahrul Ulum. Bairut Libanon: Darul Kutub Al-Ilmiyyah.

Sa'dy, Al-Allamah As-Syaikh Abdurrahman bin Nashir As. 2000. Tafsirul alKarim Ar-Rahman fi Tafsir Kalam Al-Mannan. Tanpa Kota: Muassasah Ar-Risalah.

Sugiyono. 2014. Metode Penelitian Pendidikan Pendekatan Kuantitatif, Kualitatif, dan RED. Bandung: Alfabeta.

Shiddiqy, Tengku Muhammad Hasbi Ash. 1995. Tafsir Al-Qur'anul Majid AnNur. Semarang: Pustaka Rizki Putra Semarang. 1990. Sejarah dan Pengantar Ilmu al-Qur'an/Tafsir. Jakarta:

Bulan Bintang.

Shon'any, Al-Imam Al-Muhaddist Abdur Rozzaq bin Hammam Ash. 1999. Tafsir Abdur Rozzaq. Bairut Libanon: Darul Kutub Al-Ilmiyyah.

Shobuny, Ali. 1999. Rowai'u Al-Bayan Tafsir Ayat Al-Ahkam min Al-Qur'an. Madinah: Dar AshShobuny.

Suyuti, Jalaluddin as. 1979. Al-Itqan fi Ulumil Al- Qur'an, Juz II. Bairut: Dar AlFikr. 
Syaukany, Al-Imam Muhammad bin Aly bin Muhammad Asy. 2003. Fathul Qodir. Diakse melalui www.altafsir.com.

Thobari, Abi Jakfar Muhammad Jarir Ath. 2001. Tafsir Ath-Thobary: Jamiul Bayan 'an Ta'wil Al-Qur'an Juz 16. Jizah: Dar Al-Hajar.

Thobarisy, Al-Imam Asy-Syaikh Abi Aly Al-Fadl bin Al-Hasan bin Al-Fadl Ath. 1998. Majma Al-Bayan fi Tafsiril Qur'an. Bairut Libanon: Darul Kutub Al-Ilmiyyah.

Thobatobai, Al-Alamah Syayid Muhammad Husain. 1991. Al Mizan fi Tafsiril Qur'an. Beirut, Libanon: Muassatul 'alamy.

Qosimy, Al-Imam Al-Allamah Muhammad Jamaluddin Al-. Tafsir Al-Qosimiy. Bairut Libanon: Darul Kutub Al-Ilmiyyah.

Qurthuby, Abi Abdillah Muhammad bin Ahmad Al-Anshory al. 2006. Al-Jami Al-Ahkamil Qur'an. Beirut: Ar-Resalah Publisers.

Al-Jauziyah, Ibnu Qoyyim. 2000. Tafsir Ibnu Qayyim, terjemahan Indonesia Kathur Suhardi. Jakarta Timur: Darul Falah.

Yasu'iy, Louis Ma'luf. 1996. Al-Munjid fi Al-Lughoh, cet, 10. Bairut: Dar AlMasyiq.

Zuhaily, Wahbah. 2000. Al-Tafsir al-Wasith. Bairut Libanon: Darul Fikr AlMaashir.

1998. Al-Tafsir Al-Muniir fi alAqidah wa asyari'ah wa alManhaj. Bairut Libanon: Darul Fikr Al-Maashir.

Zamakhsari, Al-Imam Abi Qosim Jarulloh Mahmud bin Umar bin Muhammad Az-.1998. Al-Kasysyaaf 'An Haqaa'iq at-Tanziil Wa 'Uyuun al-Aqaawiil Juz 4. Riyadh: Al-Abikan.

Zarkasy, Al-Imam Badruddin Muhammad bin Abdillah Az-. 1998. Al-Burhan fi Ulumil Qur'an. Bairut Libanon: Darul Fikr. 